\title{
Effects of zinc supplementation on 1- to 5-year old children
}

\author{
Adriana P. R. Silva, ${ }^{1}$ Márcia Regina Vitolo, ${ }^{2}$ Luis Fabrício Zara, ${ }^{3}$ \\ Carlos Frederico S. Castro 4
}

\begin{abstract}
Objective: To assess the impact of zinc supplementation on nutritional and biochemical parameters among children aged 12 to 59 months.

Methods: A blinded randomized clinical trial was carried out with 58 children aged 12 to 59 months included in the Programa Governamental de Combate a Carências Nutricionais (National Child Nutritional Program), which provided them with $2 \mathrm{~kg}$ of iron-fortified milk. The supplementation group $(n=28)$ received $10 \mathrm{mg} /$ day of zinc sulfate for four months, and the control group $(n=30)$ received placebo. The following parameters were used to assess the nutritional status: weight-for-height and height-for-age expressed as z scores, according to National Center for Health Statistics (NCHS) standards, biochemical measurements of serum iron and serum zinc, and hemoglobin and hematocrit levels.
\end{abstract}

Results: Zinc supplementation did not have a remarkable influence on anthropometric parameters. Baseline serum zinc levels were low in both groups. After supplementation, variations in mean hemoglobin $(p=0.002)$, hematocrit $(p=0.001)$, serum zinc $(p=0.023)$, and serum iron $(p=0.013)$ levels significantly increased in the zinc supplementation group.

Conclusion: Zinc supplementation improved hemoglobin response and normalized serum zinc concentration. The results show the importance of establishing policies for nutritional care that can tackle zinc deficiency as well.

J Pediatr (Rio J). 2006;82(3):227-31: Nutritional risk, micronutrients, supplementation, child feeding.

\section{Introduction}

After the sixth month of life, iron and zinc requirements of infants must be provided by complementary foods, so that the bodily demand for these micronutrients can be met. ${ }^{1}$ Appropriate intrauterine development and exclusive breastfeeding are a guarantee that an infant's requirement

1. Programa de Pós-Graduação (Doutorado), Faculdade de Ciências da Saúde, Universidade de Brasília (UnB), Brasília, DF, Brasil. Mestre, Instituto de Nutrición y Tecnología de los Alimentos (INTA), Universidad de Chile, Santiago, Chile. Nutricionista docente, Universidade Católica de Brasília (UCB), Brasília, DF, Brasil.

2. Programa de Pós-Graduação em Ciências Médicas, Fundação Faculdade Federal de Ciências Médicas de Porto Alegre (FFFCMPA), Porto Alegre, RS, Brasil.

3. Químico. Professor Doutor, Departamento de Química, UCB, Brasília, DF, Brasil.

4. Químico. Professor Doutor, Diretor, UCB, Brasília, DF, Brasil.

Materials supplied by: Shering S.A. Indústria Farmacêutica (supply of zinc sulfate) and Farmacotécnica (preparation and supply of solutions used in the study).

Manuscript received Sep 12 2005, accepted for publication Mar 022006.

Suggested citation: Silva AP, Vitolo MR, Zara LF, Castro CF. Effects of zinc supplementation on 1 - to 5 -year old children. J Pediatr (Rio J). 2006;82:227-31 of iron and zinc will be met during the first six months of life. However, after this period, complementary foods should meet such demand, which may be more complicated in the second and third years of life. ${ }^{2}$ In the last few years, zinc deficiency has been of great importance to developing countries, ${ }^{3}$ due to the low intake of animal protein and high intake of phytates. ${ }^{4,5}$

The diagnosis of zinc deficiency is often based on clinical manifestations, such as dermatitis, failure to thrive, hypogonadism, dysgeusia, and anorexia. 6,7 Measurement of plasma zinc levels is key to determining the dietary intake of zinc in infants and children. 8 There is some evidence that malnourished children gain weight more quickly when they are given zinc supplementation.9,10

Zinc deficiency affects the growth hormone (GH) metabolism, and may be a limiting factor in growth regulation. ${ }^{11-13}$ Results of a meta-analysis have shown that zinc supplementation has a positive effect on the growth of malnourished children with low plasma zinc levels. ${ }^{14}$ The status of zinc deficiency in Brazil is still 
unknown; ${ }^{15}$ therefore, the aim of this study was to assess the effect of zinc supplementation on nutritional parameters (weight, height, levels of hemoglobin, hematocrit, serum iron and serum zinc) of children younger than five years enrolled in the National Child Nutritional Program, which distributes iron-fortified, milk-based formulas in São Sebastião, Distrito Federal (DF).

\section{Methods}

We carried out a randomized, blinded, placebocontrolled clinical trial in which participants received either zinc sulfate or placebo. Study participants were from lowincome families and lived in São Sebastião (DF), a town with around 70,000 inhabitants, and all of them were enrolled in the National Child Nutritional Program. The aim of this program is to provide children aged 12 to 59 months at nutritional risk with $2 \mathrm{~kg}$ of cow's milk powder fortified with $10 \mathrm{mg}$ of iron per $100 \mathrm{~g}$ of milk every month, given out at local health centers. In order to calculate the sample size, we estimated the prevalence of anemia to be $50 \%$ at the beginning of the study, before zinc supplementation, with a $13.5 \%$ decrease after supplementation. Given a $5 \%$ significance level and an $80 \%$ power, the sample consisted of 60 individuals, who were randomly placed in two groups. The following exclusion criteria were used: diseased children, anemic children with hemoglobin levels lower than $9.0 \mathrm{~g} / \mathrm{dl}$, children on medication or receiving supplementation, and those with parasitic disease. Mothers or surrogates were asked whether they allowed their children to participate in the study, and could decline participation or withdraw their children at any time. Before supplementation, all children were clinically examined by a pediatrician. Eligible children were randomly chosen by a health agent from the research team, who was not directly involved in the sampling. The children were placed in either of two groups according to the supplementation they received. Of every two mothers or surrogates who allowed their children to participate in the study, one child was assigned to the supplementation group and another one was placed in the control group until the total sample size was reached. The study was conducted between May and August 2002 in São Sebastião (DF).

\section{Supplementation group}

This group received $10 \mathrm{mg}$ of zinc/5 $\mathrm{ml}$ of solution, given once a day for four months. The flask containing zinc sulfate was labeled $\mathrm{S}$.

\section{Control group}

The control group received $5 \mathrm{ml}$ of a syrup (placebo) a day for four months. The flask containing the syrup was labeled C.
The flasks containing placebo and zinc sulfate were identical and the taste and smell of the solutions were the same. The raw material was supplied by a pharmaceutical laboratory in São Paulo, and the solutions were prepared and supplied by a pharmaceutical laboratory in the city of Brasília (DF). The supplement was given every morning, preferably under fasting conditions. Mothers or surrogates were not instructed to change their children's dietary habits during the study period. Information about the acceptance of milk, supplemental zinc and placebo, possible gastrointestinal symptoms (nausea, vomiting, diarrhea), and loss of appetite caused by zinc supplementation, and anthropometric measurements were recorded on the participants' medical charts.

\section{Anthropometric measurements}

Children aged 24 months or less were weighed on a digital scale, whereas those aged up to 59 months were weighed on a manual anthropometric scale. Length and height were measured according to international standards. ${ }^{16}$ The nutritional status was assessed by heightfor-age $(\mathrm{H} / \mathrm{A})$ and weight-for-height $(\mathrm{W} / \mathrm{H})$ expressed as z score, according to NCHS standards. ${ }^{17}$ Epi-Info version 6.04 was used for data entry. A cutoff point of $<-2$ SD and a normal level of > -2 DP were used to determine low weight-for-height and low height-for-age.

\section{Biochemical analysis}

The children were referred to the laboratory of a health center in São Sebastião (DF) for venous blood specimen collection, between 7:30 a.m. and 8:30 a.m., after a 12hour fasting period. Later on, blood samples $(5 \mathrm{ml})$ were collected in polyethylene tubes containing EDTA as anticoagulant. The measurements of hemoglobin and hematocrit levels were made using the colorimetric method and were analyzed by Cell-Dyn 3800. Serum iron and serum zinc concentrations were measured by flame atomic absorption spectrophotometry (Perkin-Elmer, model 5100, $A A-660)$. Iron and zinc concentrations were measured in duplicate. The World Health Organization (WHO) ${ }^{18}$ criteria were used as cutoff points for the diagnosis of anemia. The borderline levels according to these criteria are as follows: $<11 \mathrm{~g} /$ dl for hemoglobin, $<30 \%$ for hematocrit, $<45 \mu \mathrm{g} / \mathrm{dl}$ for iron deficiency, and plasma levels lower than $70 \mu \mathrm{g} / \mathrm{dl}^{19}$ for zinc deficiency, for both males and females.

\section{Statistical analysis}

We used SSPS version 10 for the statistical analysis. The significance level was set at $5 \%$, and the following tests were performed:

1. Student's $t$ test with unequal variances to compare the mean levels of serum zinc and serum iron between children who received zinc supplementation and those 
who did not; Student's $t$ test for independent samples to compare the mean levels of hemoglobin and hematocrit, as well as the weight and height, of children in the supplementation and in the control groups. Paired Student's $t$ test to compare the differences between initial and final $\mathrm{W} / \mathrm{H}$ and $\mathrm{H} / \mathrm{A} \mathrm{z}$ scores.

2. Analysis of variance for non-independent groups: to compare initial and final scores with repeated measures for weight, height, hemoglobin and hematocrit.

3. Chi-square test, when the groups were compared in terms of percentage of children with anemia at the beginning and at the end of the study.

The present study was approved by the Research Ethics Committee of Universidade de Brasília (UnB).

\section{Results}

Of 107 children, 40 voluntarily withdrew from the study and seven were excluded (two of them due to hemoglobin levels lower than $9 \mathrm{~g} / \mathrm{dl}$, three due to giardiasis, and two for being on ferrous sulfate supplementation). Of the remaining 60 children, 30 were placed in the supplementation group and 30 in the control group. In the course of the study, two children from the supplementation group withdrew. All excluded children, except those who changed address, were sent to a pediatrician for follow-up and/or treatment.

The final sample consisted of 58 children (28 in the supplementation group and 30 in the control group), $56.9 \%(n=33)$ of whom were female and $43.1 \%(n=25)$ of whom were male. Mean age was $23.5( \pm 7.6)$ months, and $50 \%$ of the children were aged between 12 and 24 months. Table 1 shows the mean and standard deviation of anthropometric measurements and biochemical parameters before and after zinc supplementation $(10 \mathrm{mg} / \mathrm{d})$. There were no statistically significant differences in the anthropometric measurements between the supplementation and control groups $(p=0.652)$ at the beginning of the study. The mean levels of hemoglobin, hematocrit and serum iron were normal in both groups. All children had plasma zinc levels lower than $70 \mu \mathrm{g} / \mathrm{dl}$ at the beginning of the study. After four months of supplementation, there were remarkable increases in zinc levels $(p=0.023)$, iron levels $(p=0.013)$, hematocrit $(p=0.001)$ and in mean hemoglobin levels $(p=0.002)$ in the supplementation group. Weight and height improved in both groups, without statistical difference between them. The mean hemoglobin level was $0.7 \pm 0.8 \mathrm{~g} / \mathrm{dl}$ in the supplementation group and $0.5 \pm 0.9 \mathrm{~g} / \mathrm{dl}$ in the control group ( $p=0.002$ ) during the four months of zinc supplementation. According to data not shown in the table, the occurrence of anemia before zinc supplementation amounted to $31 \%$. The age of anemic children averaged 37.4 ( \pm 4.6$)$ months. Among 18 anemic children, 13 belonged to the supplementation group and five were from the control group. At the beginning of the study, the mean hemoglobin levels of anemic children were $10.2 \pm 0.7 \mathrm{~g} / \mathrm{dl}$ and $10.9 \pm 0.1 \mathrm{~g} / \mathrm{dl}$ in the supplementation group and in the control group, respectively. At the end of the study, both groups showed a lower prevalence of anemia and a significant increase in mean hemoglobin levels, $11.3 \pm 0.4 \mathrm{mg} / \mathrm{dl}$ in the supplementation group and

Table 1 - Mean \pm standard deviation of anthropometric and biochemical parameters in the zinc supplementation group $(10 \mathrm{mg} / \mathrm{d})$ and in the control group before and after four months of intervention (São Sebastião, DF, 2002)

\begin{tabular}{|c|c|c|c|c|c|c|}
\hline \multirow[t]{2}{*}{ Parameters } & \multicolumn{3}{|c|}{ Before } & \multicolumn{3}{|c|}{ After } \\
\hline & $\begin{array}{c}\text { Supplementation } \\
\text { (28) }\end{array}$ & $\begin{array}{l}\text { Control } \\
(30)\end{array}$ & $\mathbf{p} *$ & $\begin{array}{c}\text { Supplementation } \\
\text { (28) }\end{array}$ & $\begin{array}{l}\text { Control } \\
(\mathbf{3 0})\end{array}$ & $\mathbf{p} *$ \\
\hline \multicolumn{7}{|l|}{ Anthropometric(z score) } \\
\hline $\mathrm{W} / \mathrm{H}$ & $-1.1 \pm 1.2$ & $-1.3 \pm 0.8$ & 0.326 & $0.7 \pm 1.5$ & $0.6 \pm 1.6$ & 0.275 \\
\hline $\mathrm{H} / \mathrm{A}$ & $-2.0 \pm 1.6$ & $-1.9 \pm 1.6$ & 0.737 & $-1.7 \pm 2.6$ & $-1.6 \pm 1.6$ & 0.253 \\
\hline \multicolumn{7}{|l|}{ Biochemical } \\
\hline Hemoglobin (g/dl) & $11.1 \pm 0.9$ & $11.6 \pm 1.2$ & 0.080 & $11.8 \pm 1.1$ & $12.1 \pm 0.7$ & 0.042 \\
\hline$\Delta$ Hemoglobin $(\mathrm{g} / \mathrm{dl})$ & - & - & - & $0.7 \pm 0.8$ & $0.5 \pm 0.9$ & 0.002 \\
\hline Hematocrit (\%) & $34.6 \pm 2.9$ & $35.4 \pm 3.1$ & 0.681 & $35.9 \pm 2.6$ & $35.7 \pm 3.0$ & 0.001 \\
\hline Serum iron $(\mu \mathrm{g} / \mathrm{dl})$ & $149.5 \pm 5.8$ & $146.8 \pm 5.7$ & 0.267 & $172.7 \pm 3.3$ & $160.2 \pm 4.8$ & 0.013 \\
\hline Serum zinc $(\mu \mathrm{g} / \mathrm{dl})$ & $61.0 \pm 1.7$ & $51.5 \pm 5.7$ & 0.041 & $87.3 \pm 1.6$ & $52.6 \pm 3.8$ & 0.023 \\
\hline
\end{tabular}

$\mathrm{H} / \mathrm{A}=$ height-for-age; $\mathrm{W} / \mathrm{H}=$ weight-for-age

${ }^{*} \mathrm{p}<0.05$. 
$11.8 \pm 0.3 \mathrm{mg} / \mathrm{dl}$ in the control group ( $p=0.021)$. A $25 \%$ decrease in the prevalence of anemia occurred in the supplementation group against a $6.6 \%(p=0.032)$ decrease in the control group. Acceptance of fortified milk corresponded to $100 \%$, and of supplemental zinc, to $98 \%$. Appetite improved by $64.3 \%(n=18)$ in the supplementation group and by $23.3 \%(n=7)$ in the control group ( $p=0.001)$.

\section{Discussion}

The poor nutritional status of children at the beginning of the study was expected, since these children were enrolled in a nutritional recovery program.

Marginal zinc deficiency has been attributed to the low intake of zinc-rich foods, as well as to the low bioavailability of zinc, especially in foods of vegetable origin. 20 In this study, serum zinc deficiency was observed in all children, but zinc levels were restored after supplementation. Zinc supplementation is recommended for short periods, mainly for individuals who are at risk of mineral depletion.

The growth of children who received zinc supplementation was not better than that observed in the control group. Twenty-five trials conducted to assess the effect of zinc supplementation on growth, using the same substance as in this study (zinc sulfate) did not show any differences between the effect on growth and the type of supplementation used. ${ }^{21}$ Impaired growth may be due to the sample size, to the short supplementation period or to the deficiency of nutrients, other than zinc, which are also important to children's growth; ${ }^{22}$ however, further studies are necessary in order to confirm this finding. After zinc supplementation, hematocrit levels and variations in hemoglobin levels increased significantly, and so did the iron and zinc concentrations. There was a $25 \%$ decrease in the prevalence of anemia in the supplementation group against a $6.6 \%$ decrease in the control group. The effect of zinc on biochemical parameters may represent the participation of this nutrient in iron metabolism, regulating the function and expression of divalent metal transporter 1 (DMT1) and iron-regulated (IREG) mRNA. ${ }^{23}$ Previous studies of Indonesian children 24,25 using iron supplementation and zinc supplementation separately (10 $\mathrm{mg}$ ), combined supplementation of zinc and iron, and placebo-controlled, showed a positive effect on the reduction in the prevalence of anemia and on iron and zinc deficiencies. However, the reduction in the prevalence of anemia and the increase in hemoglobin and ferritin levels were higher in the group that received only iron supplementation. The inconsistent results obtained by these studies may be due to age differences, which ranged from 4 to 12 months in Indonesian studies, and from 12 to 59 months in the present study, suggesting different maturities for the mechanisms that regulate iron transport, previously demonstrated by an experimental animal study. ${ }^{26}$ These data reveal that when implementing programs for micronutrient supplementation one should take the target age range into consideration, since the effects may differ. Special attention should be given to the fact that the control group in the present study consisted of children who received iron-fortified milk, which partly justifies the positive result observed in mean hemoglobin levels at the end of the study. The inhibitory effects between iron and zinc only occur at high molar concentrations (Fe:Zn,25:1). ${ }^{27}$ As to the increase in appetite reported by the mothers, zinc supplementation may be efficient in restoring the children's appetite for salt-containing foods, as shown in another study; ${ }^{28}$ however, the methodology used in the present study does not allow us to confirm this finding.

\section{Conclusion}

Zinc supplementation remarkably increased the variation in hemoglobin, hematocrit, serum iron and serum zinc levels, compared to the results found for the group that only received iron-fortified milk. The improvement of some biochemical parameters in the supplementation group shows the effect of the deficiency of other micronutrients on the iron status of children. This result reveals the importance of establishing efficient policies that can tackle generalized deficiency of micronutrients or "hidden hunger". The prevalence of zinc deficiency in Brazil is unknown; thus, it is necessary to investigate it further so as to establish a safe and appropriate intake of this mineral among preschoolers.

\section{Acknowledgements}

We would like to express our thanks to the mothers and pediatricians who participated in this study. Also our thanks to Professor Egle Machado Siqueira for her encouragement, and to the technicians from the chemical analysis laboratories of Universidade Católica de Brasília (UCB) and of the Health Department of Distrito Federal.

\section{References}

1. Institute of Medicine. Dietary reference intakes: applications in dietary assessment. Washington: National Academy Press; 2000.

2. Organização Mundial da Saúde. Elementos traços na nutrição e saúde humana. São Paulo: Rocca; 1998.

3. Allen LH. Zinc and micronutrient supplements for children. Am J Clin Nutr. 1998;68(Suppl 2):495-8.

4. Baker $\mathrm{DH}$, Ammerman $\mathrm{CB}$, Lewis A. Bioavailability of nutrients for animal: amino acids, minerals, and vitamins. San Diego: Academic Press; 1995. p. 367-98.

5. Hambidge KM, Krebs NF, Miller L. Evaluation of zinc metabolism with use of stable isotope techniques: implication for the assessment of zinc status. Am J Clin Nutr. 1998;68 Suppl 2: 410-3. 
6. Evans GW. Zinc and the its deficiency diseases. Clin Physiol Biochem. 1986;4:94-8.

7. Blom I, Jameson S, Krook F. Zinc deficiency with transitory acrodermatitis enteropathica in low birth weight. Br J Dermatol. 1990;104:459-64.

8. Brown KH, Person JM, Allen LH. Effects of zinc supplementation on children growth: a meta-analysis of intervention trial. Bibl Nutr Dieta. 1998;54:76-83.

9. Golden BE, Golden MHN. Effect of zinc in tissue synthesis during recovery from malnutrition. Eur J Clin Nutr. 1992;46:697-706.

10. Penny M, Marin RM, Duran A, Peerson JP, Lanata CF, Lonnerdal, et al. Randomized controlled trail of the effect of daily supplementation with zinc or multiple micronutrients on the morbidity, growth, and micronutrient status of young Peruvian children. Am J Clin Nutr. 2004;79:457-65.

11. Nishi Y. Zinc and growth. J Am Coll Nutr. 1996;15:340-4.

12. Brown K. Suplementación con zinc y crecimiento en niños: una meta análisis de estudios de intervención. Dieta y Salud. 1995; 4:1-7

13. MacDonald RS. The role of zinc in growth and cell proliferation. J Nutr. 2000;130:1500-8.

14. Brown KH, Peerson JM, Rivera J, Allen LH. Effect of supplemental zinc on the growth and serum zinc concentrations of prepubertal children: a meta-analysis of randomized controlled trials. Am J Clin Nutr. 2002;75:1062-71.

15. Favaro RMD, Vannucchi $H$. Níveis plasmáticos de zinco e antropometria de crianças da periferia de centro urbano no Brasil. Rev Saude Publica. 1990;24:5-10.

16. Jelliffe DB. Evaluación del estado de nutrición de la comunidad. Genebra: Organización Mundial de La Salud; 1968.

17. World Health Organization. Physical status: the use and interpretation of anthropometry. Geneva: WHO; 1995. (Technical Report Series no. 854).

18. Organización Mundial de la Salud. Lucha contra la anemia nutricional, contra la carencia de hierro. Genebra: OMS; 1975. (Serie de Informes Técnicos no 580).

19. Hambidge KM, Walravens PA, Brown RM, Webster J, White S, Anthony $M$, et al. Zinc nutrition of preschool children in the Denver Head Start Program. Am J Clin Nutr. 1976;29:734-8.
20. Brown $\mathrm{KH}$, Wuehler SE, Peerson JM. The importance of zinc in human nutrition and estimation of the global prevalence of zinc deficiency. Food Nutr Bull. 2001;22:113-25.

21. Allen LH. Zinc and micronutrient supplements for children. Am J Clin Nutr. 1998;68:495-8.

22. Hambidge KM. Human zinc deficiency. J Nutr. 2000;130 Suppl 1:1344-9.

23. Yamaji S, Tennant J, Tandy S, Williams M, Srai SKS, Sharp P. Zinc regulates the function and expression of the iron transporters DMT1 and IREG1 in human intestinal Caco-2 cells. FEBS Lett. 2001;507:137-41.

24. Dijkhuizen MA, Wieringa FT, West CE. Effects of iron and zinc supplementation in Indonesian infants on micronutrient status and growth. J Nutr. 2001;131:2860-5.

25. Lind T, Lonnerdal G, Stenlund $H$. A community-based randomized controlled trial of iron and zinc supplementation in Indonesian infants: interactions between iron and zinc. Am J Clin Nutr. 2003;77:883-90.

26. Leong WI, Bowlus CL, Tallkvist J, Lonnerdal B. Iron supplementation during infancy - Effects on expression of iron transporters, iron absorption and iron utilization in rat pups. Am J Clin Nutr. 2003;78:1203-11.

27. Pizarro F, Olivares M, Kain J. Hierro y zinc en la dieta de la población de Santiago. Rev Chil Nutr. 2005;32:19-27.

28. Campos Jr, Veras N, Magno C, Silva F, Valeriano L, Leite MF, et al. Suplementação com zinco pode recuperar apetite para refeições de sal. J Pediatr (Rio J). 2004;80:55-9.

Correspondence:

Adriana Pederneiras Rebelo da Silva

Condômino Mônaco DF, 140, km 2, quadra 13, casa 04, Lago Sul

CEP 71680-601 - Brasília, DF - Brazil

Tel.: +55 (61) 3335.0416

Fax: +55 (61) 3328.3078

E-mail: adriana.pederneiras@terra.com.br 